\title{
A Comparative Study of Cultural Dimensions and Motivation Level of Pakistani and American Female Managers
}

\author{
${ }^{1}$ Usman Qayyum Qureshi, ${ }^{2}$ Asst Prof Nain Tara Sarfraz Raja \\ ${ }^{1}$ Foundation University Institute of Engineering \& Management Sciences, New Lalazar, \\ ${ }^{2}$ Foundation University Institute of Engineering \& Management Sciences, New Lalazar, Rawalpindi Cantt.
} Pakistan.

\begin{abstract}
Culture is an important part of every individual's life. It determines an individual's life style. In every field of life there is a culture which creates or maintains the working of that field. If we talk about the cultural differences in working environment of Pakistan and America we can easily see a big difference and when it comes to the working women the gap or the difference goes even bigger. Women have been seen as different from men, universally lacking the necessary personal characteristics and skills to make good managers. The attitude and belief of employees in American and Pakistan depends on educational and economic development. The methodology adopted for study would be quantitative analysis with sample size of $n=200$ employees. The hypothesis generated had been evaluated through SPSS which shows that culture influence positively on American and Pakistani females. The level of motivation between Pakistani and American female also shows no significant difference.
\end{abstract}

\section{Introduction:}

A culture is a way of life of a group of people, the behaviors, beliefs, values and symbols that they accept generally without thinking about them and they are passed along by commutation and imitation from one generation to next generation.

Culture is an important part of every individual's life. It determines an individual's life style. Every country of this world has its own culture even there are more than one cultures in a country. In every field of life there is a culture which creates or maintains the working of that field.

If we talk about the cultural differences in working environment of Pakistan and America we can easily see a big difference and when it comes to the working women the gap or the difference goes even bigger.

In America there is a large no of women who work. The work place culture is so that women are more involved in work and supporting them self in order to contribute to the society as well as meeting there economic needs. The freedom of work and education level is the factor which encourages them to work.

In a society like Pakistan where conservative thoughts are still there working women face more difficulties than an American women. Firstly the educational level in Pakistani women is not as higher as in America. In the remote areas of Pakistan women still do not have the freedom to go to school but still there is a class of women which can be said working class.

The comparison between American and Pakistani working women with respect to cultural dimension i.e. power distance, individualism, achievement, uncertainty avoidance and long term orientation shows not much of difference.

When you compare the motivational level of the Pakistani working women and American women do we see any difference? If yes than what are the factors behind this difference and if not then why? These are the questions that are being answered in the study on the basis of analysis of both the countries.

Motivation of an employee instigates them to perform work with more dedication as there exist, two kinds of factors that enhance motivation. Intrinsic and extrinsic motivation has two influences on internal and external characteristics of employees. Factors like Passion and energy, respect and trust and pay strategy improve level of motivation. The flexibility in working hours and working schedule let them work with confidence and passion (Patti Holmes, 2002)

\subsection{Problem statement:}

Considering the aforesaid discussion, the researcher has decided to make a detail analysis of cultural dimensions and motivation level of Pakistani and American female managers.

\subsection{Originality of study:}

In South Asia IT jobs with virtual and direct representation with diversity concerns manage workplace duality. In South Asia and America work place discrimination, career gender and relationship preferences manage long term decision making. The IT career willingness and ability with subordinated social position with 
workforce manage social expectation. The IT sector men and women skills and inclination recognizes individual differences. Culture impacts on value systems, beliefs and structures with complex social practices. The previous study was conducted by Monica P ADYA in Asia and America. However in this paper, the cultural dimensions and level of motivation of Pakistani IT workers (women) would be analyzed and compared with American women.

\subsection{Applied aspect:}

The purpose of paper is to investigate work force diversity practices in US and Asian countries. The career challenges faced in context with social, cultural and economical factors Asian women through mentoring relationship and copying mechanism. The IT sector in US is developing due to Asian and Middle Eastern influx of International talent like 3\% Hispanic and $0.95 \%$ non Hispanic people. For most of organizations in America IT workforce has virtually and directly induced Asian women presence due to gender and race duality. In paper Hofstede dimension for power distance, individualism, masculinity, uncertainty avoidance and long term orientation manage comparative assessment. The values, beliefs and artifacts characterize difference in challenges.

\subsection{Objective of study:}

The objective of study lies in:

- To analyze work force practice difference in Pakistan and America.

- To find out the differences in motivation level and impact of cultural dimensions on working style of women in both countries.

\section{Literature Review:}

The female training and experience to contribute workforce diversity, overcrowding labor markets for wage down and wage drive engage them to work (Anker, 1997). In teaching profession women were given importance while subordinate social positioning, gender discrimination and care provision defines societal experience.

The institutional and cultural factors for group level emphasis like shared perception recognizes IT skill and inclination (Queensberry and Morgan, 2004). The participation of gender with variation in individual differences manages work responses and situations. Culture impact on essentialism and constructivism involve engineering participation (Weinrich Haste and Newton, 1983).

The social issues access to education and economic paradoxes by cultural strategies and processes set values. The socio economic demands for workplace relationship by entertaining stress level manage personal trait. The harmonious interpersonal conflicts and tolerant personalities manage social and economic level. The gender skills, efforts and responsibility relevant to pay expectation regulated through profession by predictable pay check. Daily pressures for bureaucratic structure manage through Gini Index of 41 as female participation in rural and urban subdivision work through wage distribution. The policy decisions in cultural and national environment manage by severe and frequent socio economic factors. In Pakistan level of stress is higher due to lack of resources and bureaucratic structural environment. In private sector higher perception by employability and environmental challenges effect work. The cultural differences at competitive work place impact on task and performance. (Dr.TalatAfza ,Dr.Bahaudin G. Mujtaba and Naseemhabib, 2011)

Sex-role stereotyping has been identified as one of the most important barriers to women's progress in the workplace. ( Fullagar, Sumer, Sverke, \& Slick, 2003).

The equal pay act 1963 for working conditions characterize by managerial job characterization. The analytical and communication skills for corporate social responsibility and standardization manage through pay satisfaction. The career characteristics for cultural fit by working ability provide benefit to customers. The turnover and gender differences for interpersonal and societal contribution prioritize working experiences. The employment opportunities for intensity and perception on women, men education defines occasional job distribution. The career characteristics for attracting, hiring and recruiting diverse market by social aspects in promotional opportunity, flexibility and work life balance determine employment understanding. The awareness, sensitivity and social aspects manage through effective policies and practices ( Lori J. Sallop , Susan L.Kirby,2007)

The gender identity for career choice in managerial and careerism manage potential conflict by job identity. The organization structure and occupational choice in dominant position lead to monolithic women oppression. The social relation perspective for ambiguity, flexibility and social practices lead to attitudinal development. The polarization, assimilation and visibility in working environment define effective organizational characteristics. Career aspiration, motivation and activities for incorporation manage differentiation in practices. The hegemonic structural implications for gender work manage hierarchy for 
performance determining. The performance in context with organization through diversity and homogeneity leads to effective learning experiences (Dr Ruth Simpson, 2007)

Level of motivation relevant to particular job force them to perform with more dedication. Certain roles like interpersonal, information and decision making guides an employee to manage working environment. The decisions making ability help them to fulfill and achieve goals and produce results with minimum losses. (Mintzberg, 1973)

The need for achievement plays a major role in motivating women to become entrepreneurs. Further, the nomadic culture of adventurism, secular culture of feminism and Asian culture of collectivism play important roles in motivating and supporting women to become successful entrepreneurs. ( Majid Aramand, 2013)

The qualities associated with being a successful manager have been associated with masculinity, such as ambition, objectivity and an authoritative manner. Women have been seen as different from men, universally lacking the necessary personal characteristics and skills to make good managers. The entry of women into senior levels within organizations over the last decade or so has brought this stereotype into question (Wackman 1996). Examples of the stereotype are as follows (Owen and Todor 1993; Arıkan 1997):

-Women tend to place family demands above work considerations.

- Women work for supplemental income; as a result, they lack the necessary drive to succeed in business.

- Women are tended to mix their personal and professional beliefs /feelings, and for this reason, they are accepted as emotional not professional.

-Women are unsuitable for top managerial positions because they are too emotional and lack of some qualities necessary for managerial positions such as aggressiveness, risk-taking and decisiveness etc.

- Women managers have the self-confidence problem.

-Women managers are not motivated through power needs but affiliation motives.

- Women executives are not well-educated and experienced to undertake managerial responsibilities.

Because of these negative beliefs, women make slow progress up the organizational hierarchy. In addition to these stereotypes, there are some other obstacles that prevent women reaching managerial suits such as low participation in male networks that limits their access to decision-making processes about promotion, negative discrimination against women in hiring and promoting policies, and the negative attitudes of employers and subordinates toward women managers. (Dr. Semra Güney, Raheel Gohar, Sevcan Kılıç Akıncı, Mehmet Mutlu Akınc)

A study conducted by Everett, Thorne and Danehower (1996) summarizes the results of several studies as follows: Ezell, et al. (1981) found a direct relationship between the experience of being supervised by women and attitudes toward the motivation of women to manage. Thus, they concluded that stereotyped beliefs about women in management may be dispelled over time.

\subsection{Theoretical framework:}

Considering the literature review, following theoretical framework has been proposed. Independent Variable

Dependent Variable

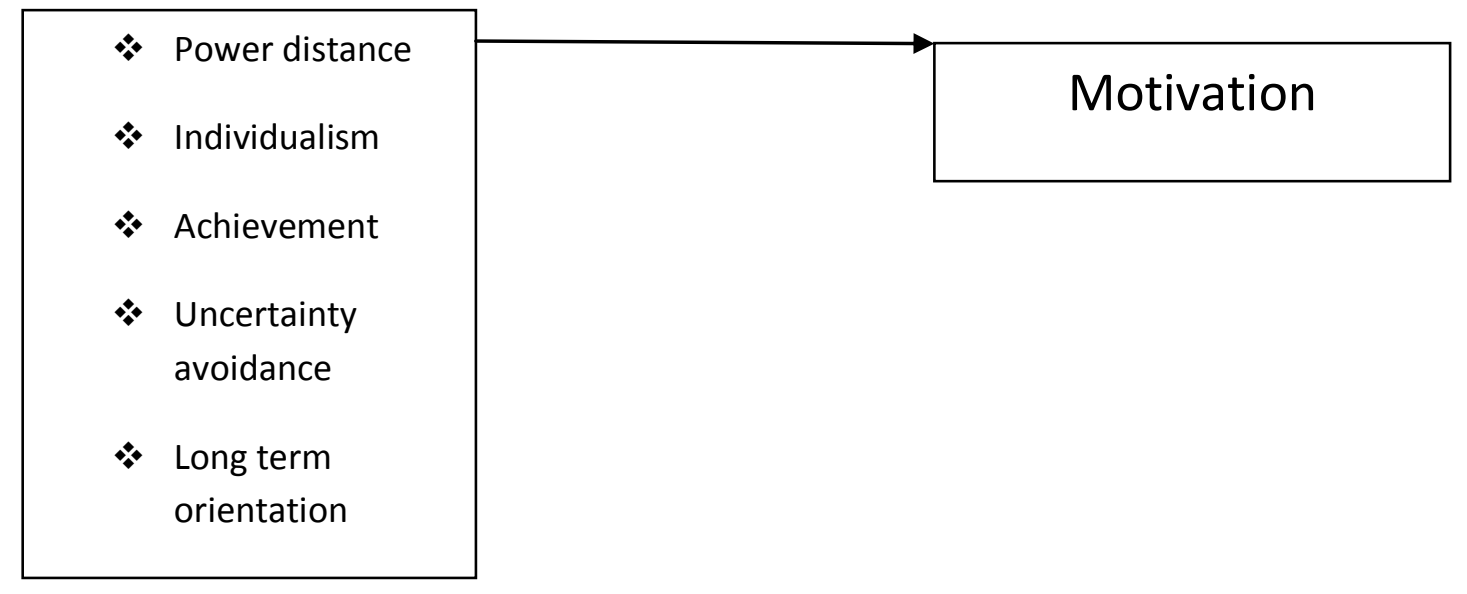

2.2 Definition of Variables:

2.2.1 Power distance: The culture effects and guidance to manage society inequalities

2.2.2 Individualism: The collective and individual rights for managing change behavior and attitudes 2.2.3 Achievement: The achievement, material success and assertiveness relevant to culture guidance 
2.2.4 Uncertainty avoidance: The ambiguity and uncertainty for degree management and comfortable guidance ( Leidner and Kayworth, 2006)

2.2.5 Long term orientation: The traditional values, attitudes and experiences to commit societal challenges

2.2.6 Motivation: Internal ability that instigates to perform work with more passion and devotion.

\subsection{Hypothesis Generation:}

H1: There is a significance difference between cultural dimension of Pakistani and American female managers.

H2: There is significance difference between the motivational level of Pakistani and American female mangers.

\section{Methodology:}

Analysis is done through correlation and independent sample t-test. Primary data includes questionnaire and women were analyzed to get appropriate responses. A sample of $n=200$ people were included to get required results. The organization chosen for study is EDEXCEL and INNEXIV firm working on software development in Rawalpindi and Islamabad respectively. To get data from firms in USA i.e. Medical Transcription Billing Co and Cure MD located in Texas, electronic copy of questionnaire was sent via an email. The response rate was $100 \%$. The research instrument involved in the research to obtain data was questionnaire.

\section{Data Analysis:}

\section{Group Statistics}

\begin{tabular}{|ll|l|l|l|l|}
\hline & grouping Var & N & Mean & Std. Deviation & Std. Error Mean \\
\hline PD & 1 & 100 & 3.0800 & .68349 & .06835 \\
& 2 & 100 & 3.2100 & .72110 & .07211 \\
\hline ID & 1 & 100 & 3.2950 & .68937 & .06894 \\
& 2 & 100 & 3.3450 & .81555 & .08156 \\
\hline A & 1 & 100 & 3.4800 & .77172 & .07717 \\
& 2 & 100 & 3.4850 & .67216 & .06722 \\
\hline UA & 1 & 100 & 3.5400 & .76765 & .07677 \\
& 2 & 100 & 3.5700 & .65142 & .06514 \\
\hline IO & 1 & 100 & 3.3950 & .91645 & .09164 \\
& 2 & 100 & 3.6900 & .86100 & .08610 \\
\hline
\end{tabular}

\section{Group statistics:}

1 representing item course of Pakistani women and 2 representing American women. The total no of respondent were 100 in both Pakistani and American. The group statistics represent interesting outcome. The mean of power distance is almost the same in the case of Pakistani and American women. This indicates that in Pakistani and American women have to manage and work hard to overcome the inequalities face by them. The scores of individualism, achievement, uncertainty avoidance are also the same in both the countries. These scores represent that Pakistani are as motivated and determined as their American counter parts. Despite of working conservative society like Pakistan were gender basis is common, these statistics represent the hard work exhibited by Pakistani women. However they are lacking in long term orientation scores the reason may be that Pakistan society is highly traditional and conservative and do not accept the change easily. Thus it is difficult for Pakistani women to bring that change.

\section{Independent Samples Test}

\begin{tabular}{|c|c|c|c|c|c|c|c|c|c|}
\hline & \multicolumn{2}{|c|}{$\begin{array}{l}\text { Levene's Test for } \\
\text { Equality of } \\
\text { Variances }\end{array}$} & \multicolumn{7}{|c|}{ t-test for Equality of Means } \\
\hline & \multirow[b]{2}{*}{$\mathrm{F}$} & \multirow[b]{2}{*}{ Sig. } & \multirow[b]{2}{*}{ t } & \multirow[b]{2}{*}{ df } & \multirow{2}{*}{\begin{tabular}{|l|} 
Sig. (2- \\
tailed)
\end{tabular}} & \multirow{2}{*}{$\begin{array}{l}\text { Mean } \\
\text { Difference }\end{array}$} & \multirow{2}{*}{$\begin{array}{l}\text { Std. Error } \\
\text { Difference }\end{array}$} & \multicolumn{2}{|c|}{$\begin{array}{l}95 \% \text { Confidence } \\
\text { Interval of the } \\
\text { Difference }\end{array}$} \\
\hline & & & & & & & & Lower & Upper \\
\hline $\begin{array}{l}\text { PD Equal variances } \\
\text { assumed }\end{array}$ & .005 & .944 & -1.308 & 198 & .192 & -.13000 & .09936 & -.32593 & .06593 \\
\hline
\end{tabular}




\begin{tabular}{|l|l|l|l|l|l|l|l|l|l|}
\hline $\begin{array}{l}\text { Equal variances } \\
\text { not assumed }\end{array}$ & & & -1.308 & 197.435 & .192 & -.13000 & .09936 & -.32593 & .06593 \\
\hline $\begin{array}{l}\text { ID } \\
\begin{array}{l}\text { Equal variances } \\
\text { assumed } \\
\text { Equal variances } \\
\text { not assumed }\end{array}\end{array}$ & 2.592 & .109 & -.468 & 198 & .640 & -.05000 & .10679 & -.26059 & .16059 \\
\hline A $\begin{array}{l}\text { Equal variances } \\
\text { assumed } \\
\text { Equal variances } \\
\text { not assumed }\end{array}$ & 3.130 & .078 & -.049 & 198 & .961 & -.00500 & .10234 & -.20682 & .19682 \\
\hline $\begin{array}{l}\text { UA } \\
\begin{array}{l}\text { Equal variances } \\
\text { assumed } \\
\text { Equal variances } \\
\text { not assumed }\end{array}\end{array}$ & 3.122 & .079 & -.298 & 198 & .766 & -.03000 & .10068 & -.22854 & .16854 \\
\hline $\begin{array}{l}\text { IO } \\
\text { Equal variances } \\
\text { assumed } \\
\text { Equal variances } \\
\text { not assumed }\end{array}$ & .237 & .627 & -2.346 & 198 & .020 & -.29500 & .12575 & -.54297 & -.04703 \\
\hline
\end{tabular}

\section{Mean comparison test}

As indicated in the summary statistics the mean comparison indicates that the mean difference between Pakistani and American women is insignificant on the variables of power distance, individualism, achievement and uncertainty avoidance is pointed out in the outset Pakistani women have same mean on these variables. However the means significantly change when it comes to long term orientation the t-tables states for the mean significant (-2.346) this change in the favor of American women as they have more power control for change in society. However most of the scores Pakistani and American women have little or no difference thus it can be put forth that with the exception of long term orientation or there is no difference in the motivational level of Pakistani and American women.

\section{Group Statistics}

\begin{tabular}{|c|c|c|c|c|c|}
\hline & $\begin{array}{l}\text { Grouping } \\
\text { Var }\end{array}$ & $\mathrm{N}$ & Mean & Std. Deviation & Std. Error Mean \\
\hline \multirow[t]{2}{*}{ M } & 1 & 100 & 3.5300 & .96875 & .09688 \\
\hline & 2 & 100 & 3.6200 & .83823 & .08382 \\
\hline
\end{tabular}

The mean scores of motivation of Pakistani and American are represented by group 1 and 2 respectively. The table clearly shows that there is no significant difference between motivation level of Pakistani and American women. This mean that Pakistani women are as motivated to play there role in the society. Their American counter parts despite of Pakistani are highly conservative and male dominant society.

Independent Samples Test

\begin{tabular}{|c|c|c|c|c|c|c|c|c|c|}
\hline & \multicolumn{2}{|c|}{$\begin{array}{l}\text { Levene's Test } \\
\text { for Equality of } \\
\text { Variances }\end{array}$} & \multicolumn{7}{|c|}{ t-test for Equality of Means } \\
\hline & \multirow[b]{2}{*}{$\mathrm{F}$} & \multirow[b]{2}{*}{ Sig. } & \multirow[b]{2}{*}{$\mathrm{t}$} & \multirow[b]{2}{*}{ Df } & \multirow{2}{*}{$\begin{array}{l}\text { Sig. } \\
(2- \\
\text { tailed })\end{array}$} & \multirow{2}{*}{\begin{tabular}{|l} 
Mean \\
Difference
\end{tabular}} & \multirow{2}{*}{$\begin{array}{l}\text { Std. Error } \\
\text { Difference }\end{array}$} & \multicolumn{2}{|c|}{$\begin{array}{l}95 \% \text { Confidence } \\
\text { Interval of the } \\
\text { Difference }\end{array}$} \\
\hline & & & & & & & & Lower & Upper \\
\hline $\begin{array}{l}\text { M Equal } \\
\text { variances } \\
\text { assumed }\end{array}$ & 2.554 & .112 & .703 & 198 & .483 & -.09000 & .12811 & -.34263 & .16263 \\
\hline $\begin{array}{l}\text { Equal } \\
\text { variances not } \\
\text { assumed }\end{array}$ & & & -703 & 193.993 & .483 & -.09000 & .12811 & -.34266 & .16266 \\
\hline
\end{tabular}


This table represents mean comparison of Pakistani and American women and it proves for comments at the outset that there is no significant difference between motivational level of Pakistani and American women.

\section{Conclusion:}

This research article carried out the comparative analysis of cultural dimensions and motivation level in two different working societies targeting the female gender. The results turn out to be very interesting and peculiar as it was revealed that the cultural dimensions have a positive influence on both the working American and Pakistani females despite having difference in their culture and related aspects. Adjunct to that, the level of motivation was also the same. We can deduce that the participation of working women class in Pakistan is on the high which can be easily endorsed by the result of this research article. As far as American females are concerned, the general perception about their motivation level is well known i.e. they are upbeat, motivated and exercise equal rights and this research corroborates this fact. Pakistan is a male dominating society and the participating of women in commercial and business enterprises is usually discouraged but considering the results of this research, the Pakistani women are now very energetic and motivated about their jobs just like the American working females.

The research was conducted in specific cities of both the countries so we cannot speak on the behalf of all the Pakistani and American working women. For future research, a large sample can be taken to get a diverse viewpoint on this research.

\section{References:}

[1] Anker, R. (1997). Theories of occupational segregationby sex: An overview. International Labor Review,136, 316-339

[2] Attitudes toward Women Managers in Turkey and Pakistan By Dr. Semra Güney, Raheel Gohar, Sevcan Kılıç Akınc, Mehmet Mutlu Akınc

[3] Attitudes toward Women Managers in Turkey and Pakistan By Dr. Semra Güney, Raheel Gohar, Sevcan Kılıç Akın, Mehmet Mutlu Akın Journal of International Women's Studies Vol. 8 \#1 November 2006

[4] Boyar, S., Maertz. C. P., Pearson, A. W., \&Keough, S.(2003). Work-family conflict: A model of linkagesbetween work and family domain variables andturnover intentions. Journal of Managerial Issues, 15, 175-190.

[5] Busch, T. (1995).Gender differences in self efficacyand attitudes towards computers. Journal of EducationalComputing Research, 12 , $147-158$.

[6] Fullagar, Sumer, Sverke, \& Slick, 2003. Marmenout, Katty, Women-Focused Leadership Development in the Middle East: Generating Local Knowledge (June 30, 2009).

[7] Gallivan, M., \&Srite, M. (2005). Information technologyand culture: Identifying fragmentary and holisticperspectives of culture. Information \& Organization,15(2), 295-338.

[8] Henwood, F. 1998. Engineering difference: Discourseson gender, sexuality, and work in a collegeof technology. Gender and Education, vol.10, pp.35-49..

[9] Igbaria, M., \&Baroudi, J. J. 1995 The impact of jobperformance evaluations on career advancementprospects: An examination of gender differences inthe IS workplace. MIS Quarterly, Vol.19, pp. 107-123.

[10] Majid Aramand, (2013) "Women entrepreneurship in Mongolia: the role of culture on entrepreneurial motivation", Equality, Diversity and Inclusion: An International Journal, Vol. 32 Iss: 1, pp.68 - 82

[11] Monica P. Adya 2008 , “Women at work differences in IT Career experiences and perception between South Asian an American Women " human resource management vol.47 No. 3 pp.601-635

[12] Dr.Talat Afza , Dr Bahaudin G. Mujtaba 2011, "Stress perceptions of working adults Pakistanis and Americans " International Journal of business and social sciences vol. 2 no. 5 pp. 32-40

[13] Lori J Sallop ,Susan L.Kirby 2007, "The role of gender and work experience on career and work force diversity expectation " Institute of behavioral and applied management vol. 1 no.4 pp. 122-140

[14] Chima Mordi , Hassan Adedoyin, Hakeem Ajonbadi 2011 , "Impediments to women career advancement The Nigerian Experience Economic science. vol.LXIII No. 2 pp11-22

[15] Dr Ruth Simpson 2004, "Masculinity at work: The experiences of men in female dominated occupations "Vol.18 No. 2 pp. 1-35

[16] Lois B Shaw and David Shapiro 1987 , "Women's Work plans;contrasting expectations and actual work experience " Monthly Labor review pp.7- 13

[17] Patricia J.Ohlott;Marian N. Ruderman;Cynthia D. McCauley 1994, "gender differences in managers development job experiences "The academy of management Journal Vol. 37 No. 1 pp46-67

[18] Bette Woody , Carol Weiss 1994, "Barriers to work place advancement the experiences of white female work force "Vol. 4 no. 19 pp.14-87

[19] M.Coetzee and Z.C.Bergh 2009, "psychological career resources and subjective work experiences of working adults and exploratory study "South African Business Review Vol.13 No.2 pp.1-31

[20] Hummayoun Naeem and Muhammad Iqbal Saif 2010, "Employee empowerment and customer satisfaction : Empirical evidence from banking sector Pakistan “ African Journal of Buisness management Vol.4 No.10 pp. 2028-2031

[21] James T Bond and Ellen M.Galinsky 2005, "The diverse employment experiences of older man and women inwork force "vol No.2 pp. 220 